\title{
JOHN, Jürgen, Kleinstaaten und Kultur in Thüringen vom 16. bis 20. Jahrhundert
}

\section{Patrice Veit}

\section{OpenEdition}

\section{Journals}

Édition électronique

URL : http://journals.openedition.org/ifha/1400

DOI : $10.4000 /$ ifha. 1400

ISSN : 2198-8943

\section{Éditeur}

IFRA - Institut franco-allemand (sciences historiques et sociales)

\section{Référence électronique}

Patrice Veit, « JOHN, Jürgen, Kleinstaaten und Kultur in Thüringen vom 16. bis 20. Jahrhundert », Revue de I'IFHA [En ligne], Date de recension, mis en ligne le 01 janvier 1999, consulté le 22 septembre 2020. URL : http://journals.openedition.org/ifha/1400 ; DOI : https://doi.org/10.4000/ifha.1400

Ce document a été généré automatiquement le 22 septembre 2020

(CIFHA 


\title{
JOHN, Jürgen, Kleinstaaten und Kultur in Thüringen vom 16. bis 20. Jahrhundert
}

\author{
Patrice Veit
}

1 La Thuringe est l'exemple même de l'éclatement territorial que connaît l'Empire après la Guerre de Trente Ans. Dans cet ensemble composé d'une poussière de petits États et d'autant de villes de résidence, sans métropole culturelle ni centre urbain, s'est développée pourtant une vie économique et culturelle particulièrement intense: $y$ sont associés entre autres les noms de Luther, de Schütz, de Bach, de Goethe, de Schiller, de Liszt, de Nietzsche, de Van de Velde; Erfurt et Iéna avec notamment leur université respective, Gotha, Meiningen et son théâtre dans la seconde moitié du XIXe s. (Hans von Bülow, Richard Strauss), et bien entendu Weimar en représentent les pôles. Le présent ouvrage étudie la relation si particulière pour la Thuringe entre petits États et culture dans ses aspects les plus divers et s'interroge sur les raisons de la richesse économique et culturelle en dépit du morcellement étatique. Mais ce morcellement n'est-il pas au contraire un facteur qui favorise cet essor, l'investissement culturel étant pour ces petits États une manière de s'affirmer et de compenser l'absence d'importance politique? En quoi l'éclat culturel que connaît la Thuringe au cours des différentes époques, de la Réforme au début du XIXe s., se distingue-t-il des autres régions allemandes? Les origines des différents phénomènes culturels ne sont-elles pas à rechercher dans les conditions spécifiques des structures politiques de cette région? En balayant une période qui s'étend de la Réforme jusqu'à 1918 et au tournant moderniste, les 33 contributions qui composent le livre tentent de répondre à cet ensemble de questions sous quatre grands chapitres: politique territoriale et culture aux XVIe et XVIIe ss.; économie, culture et vie publique à l'époque classique; culture politique des petits États au XIXe s.; la culture de la période post-classique et moderniste. Loin de se limiter à la culture intellectuelle et artistique et à leurs grands moments, les études de cas proposées cherchent davantage à en cerner les conditions et à examiner les différents processus qui en sont à la base. Elles portent le regard sur 
la culture politique, la vie publique et la culture quotidienne et tentent quelques comparaisons cantonnées aux régions limitrophes comme la Saxe.

2 Patrice VEIT 